информационно-вычислительного

комплекса обоснования проектов программ

и планов развития вооружения и средств

радиационной, химической и биологической защиты

\author{
Д.Н. Чешев, А.С. Дурнов, Г.В. Скобликов, Д.А. Егорушкин \\ Федеральное государственное бюджетное учреждение \\ "33 Центральный научно-исследовательский испытательный институт» \\ Министерства обороны Российской Федерации, \\ 412918, Российская Федерация, г. Вольск-18, ул. Краснознаменная, д. 1
}

\begin{abstract}
Поступила 02.02.2020 г. Принята к публикации 12.05.2020 г.
Постоянное увеличение объемов обрабатываемой информации, усиление требований к оперативности формирования проектов программ и планов военного строительства, а также к точности моделей и методик, применяемых для прогнозирования результатов деятельности в области обеспечения обороны и безопасности Российской Федерации, предопределяют актуальность комплексной автоматизации процессов обоснования перспектив развития вооружения и средств радиационной, химической и биологической защиты. Ее обеспечение возможно внедрением в практику программного управления развитием вооружения современных информационных технологий, прогрессивных методов анализа данных и усовершенствованного научно-методического обеспечения. Цель работы - создание информационно-вычислительного комплекса для поддержки принятия решений по совершенствованию системы вооружения войск РХБ защиты Вооруженных Сил Российской Федерации. Работа основывается на методах проектирования и разработки баз данных, системного анализа, реляционной алгебры, объектно-ориентированном подходе к формированию автоматизированных систем. В ходе проведения исследований разработаны концептуальные положения, определяющие схему функционирования, структуру и содержание базы данных информационно-вычислительного комплекса, организацию автоматизированной информационно-аналитической работы в интересах обеспечения принятия решений в области развития В и С РХБЗ.
\end{abstract}

Ключевые слова: база данных; вооружение и средства радиационной, химической и биологической защиты; инбормационно-вычислительный комплекс; обеспечение принятия решений; программное управление; программы и планы развития; реляционная алгебра; системный анализ.

Библиографическое описание: Чешев Д.Н., Дурнов А.С., Скобликов Г.В., Егорушкин Д.А. Кониепция создания автоматизированного информационно-вычислительного комплекса обоснования проектов программ и планов развития вооружения и средств радиационной, химической и биологической защиты // Вестник войск РХБ защзиты. 2020. T. 4. № 2. С. 160-167. https://doi.org/10.35825/2587-5728-2020-4-2-160-167

Современная методология программно-целевого планирования развития системы вооружения Вооруженных Сил Российской Федерации (ВС РФ) включает большой массив методов и моделей различного назначения, согласованное применение которых в интересах Министерства обороны России требует создания автоматизированных информаци- онных систем военного назначения. Существующие автоматизированные информационные системы и используемое в них методическое обеспечение ориентированы на обобщенную оценку процессов развития на уровне системы вооружения ВС РФ в целом. Кроме того, преобладающая в последние годы тенденция широкого внедрения автоматизированных 
информационных систем в процесс программного планирования строительства ВС РФ, которая обусловлена необходимостью решения сложных расчетных задач в большом объеме, делает актуальным создание и применение специализированной информационно-вычислительной системы поддержки принятия решений при планировании развития образцов В и С РХБЗ на базе разработанного 33 ЦНИИИ МО РФ научно-методического аппарата, учитывающего специфику РХБ защиты войск.

Цель работь - создание информационно-вычислительного комплекса (ИВК) для поддержки принятия решений по совершенствованию системы вооружения войск РХБ защиты.

Для создания такой системы необходимо проведение исследований по определению путей и способов интеграции методического обеспечения планирования развития вооружения и средств радиационной, химической и биологической защиты (В и С РХБЗ) с существующими информационными системами Минобороны России, а также с разработкой концепции создания информационно-вычислительного комплекса обоснования проектов программ и планов развития В и С РХБЗ. При этом существующие проблемы с недостатком исходных данных должны решаться неразрывно с увеличением полноты, достоверности и качества проработки информационного обеспечения программно-целевых исследований. Интеграцию научно-методического обеспечения с существующими автоматизированными системами планирования развития вооружения необходимо осуществлять как на уровне сопряжения баз данных, применяемых при обосновании программ и планов развития вооружения автоматизированных систем и комплексов, так и на уровне функциональных возможностей используемых моделей и методик.

Анализ способов локальной передачи информации. Для сопряжения (взаимосвязи) баз данных различных автоматизированных систем и комплексов существует ряд проработанных решений. В практике программирования принято использовать как локальные, так и сетевые варианты интеграции. Учитывая ограничения доступа к сетевым ресурсам, целесообразно рассматривать следующие способы локальной передачи информации [1].

Первый способ ориентируется на использование единого информационно-лингвистического обеспечения, в соответствии с которым определяется одна централизованная база данных (БД), и в зависимости от ее структуры и логики построения формируются БД всех взаимодействующих автоматизированных си- стем. Основным недостатком этого способа является излишняя «зависимость» баз данных взаимодействующих систем от одной централизованной, ограничивающая возможности по внедрению внутривидовых программных продуктов обоснования программ и планов развития вооружения, военной и специальной техники, включая В и С РХБЗ.

Второй способ заключается в использовании копий БД для различных клиентских приложений, при этом синхронизация данных обеспечивается путем копирования информации из одной базы в другую. Основным недостатком такого способа является возможность потери данных при изменении одной и той же записи в разных копиях БД.

Третий, более универсальный, способ основан на использовании программного обеспечения класса «middleware» [2]. Системы «middleware» представляют собой дополнительный уровень передачи информации между БД. Этот уровень организуется посредством вспомогательного программного обеспечения, позволяющего проводить распознавание формата передаваемого объема данных, исходящего от одного приложения, и его дальнейшую трансформацию в формат принимающего приложения. То есть система «middleware» - это отдельный программный продукт, выполняющий функцию конвертора набора данных.

Интеграция информации. Выбор способа интеграции будет зависеть от объема и качества систематизации обрабатываемой информации разрабатываемым автоматизированным информационно-вычислительным комплексом. Концептуальный подход к создаваемому информационно-вычислительному комплексу заключается в организации системного взаимодействия и обеспечения необходимой координации при использовании всего массива входных и выходных параметров вычислительных процессов в соответствии со структурой ИВК, представленной на рисунке 1 .

Согласно рисунку 1, в программном исполнении в состав ИВК предлагается включить функциональную подсистему, подсистемы хранения информации, управления комплексом и подсистему вывода данных. Главным элементом ИВК является функциональная подсистема, обеспечивающая проведение расчетных задач при обосновании программ и планов развития В и С РХБЗ и включающая пять клиентских приложений, приведенных на рисунке 1. В соответствии с принципом иерархичности приложения функциональной подсистемы будут иметь индивидуальный и системный алгоритмы функционирования в соответствии с решаемыми ИВК задачами. 


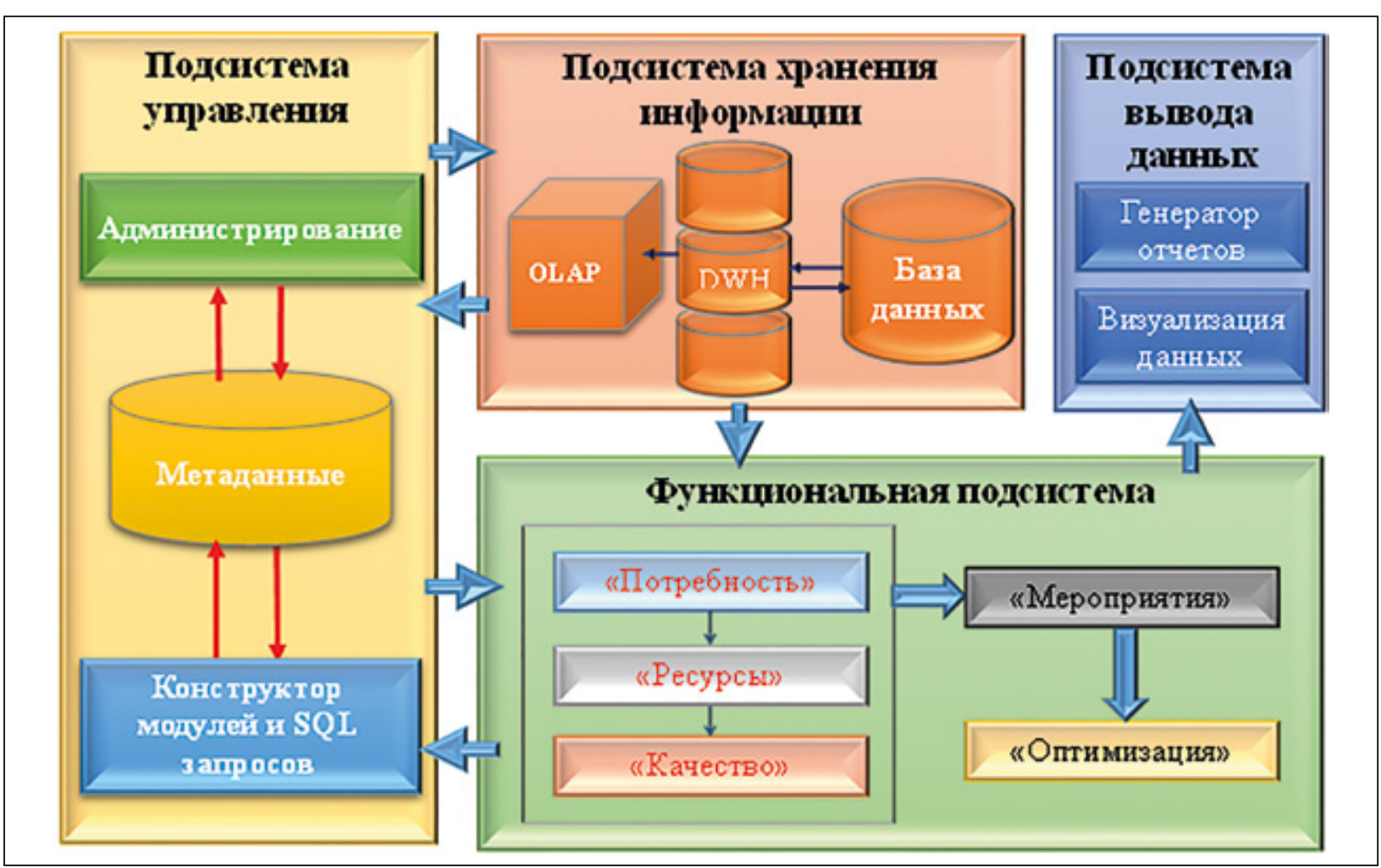

Рисунок 1 - Концептуальная структура информационно-вычислительного комплекса

Разработка системы информационного обеспечения ИВК для обоснования планов развития В и С РХБЗ в первую очередь ориентирована на обеспечение оценки качественного состояния системы вооружения для определения соответствия входящих в нее образцов предъявляемым требованиям к РХБ защите войск на окончание программного периода, категорирования образцов по моральному старению, проведение сравнительного анализа с лучшими зарубежными аналогами. Кроме того, важным элементом функционирования ИВК является определение потребностей в финансировании мероприятий развития с использованием технико-экономических показателей стадий жизненного цикла В и С РХБЗ и мероприятий государственной программы вооружения.

Состав информационной базы. Накопление различной информации военно-технического и военно-экономического характера для создания базы данных в ходе прогнозных исследований перспективного облика системы В и С РХБЗ позволит оценить ее вклад в обеспечение РХБ безопасности страны и выбрать наиболее приемлемые пути ее развития в заданном программном периоде. Для этого структурно в состав информационной базы предлагается включить четыре элемента:

1. Модуль оценки качественного развития В и С РХБЗ, содержащий сведения по образцам и их зарубежным аналогам. Он условно разде- ляется на блок с исходными данными и блок с результатами расчетов показателей, отражающих качество образцов В и С РХБЗ. Также в состав этого модуля входит дополнительная БД, содержащая информацию по наличию, исправности и современности образцов, стоящих на снабжении в подразделениях и частях ВС РФ.

2. Модуль технико-экономических параметров стадий жизненного цикла образцов, который включает блоки, содержащие фактическую и прогнозную (расчетную) информацию по технико-экономическим параметрам стадий жизненного цикла образцов.

3. Модуль справочной информации, содержащей классификатор В и С РХБЗ, коэффициенты пересчета стоимостных показателей на текущий год планирования развития, единицы измерения тактико-технических характеристик и другие данные.

4. Модуль дополнительных данных, обеспечивающий хранение метаданных и обработку промежуточных расчетов, изначально задается «пустым» и наполняется путем создания дополнительных таблиц посредством формирования необходимых SQL-запросов.

Каждый из четырех используемых модулей в функциональном отношении предназначен для информационного обеспечения решения задач по оценке качественного уровня развития образцов В и С РХБЗ, сбору статистики и прогнозированию стоимостных и временных 


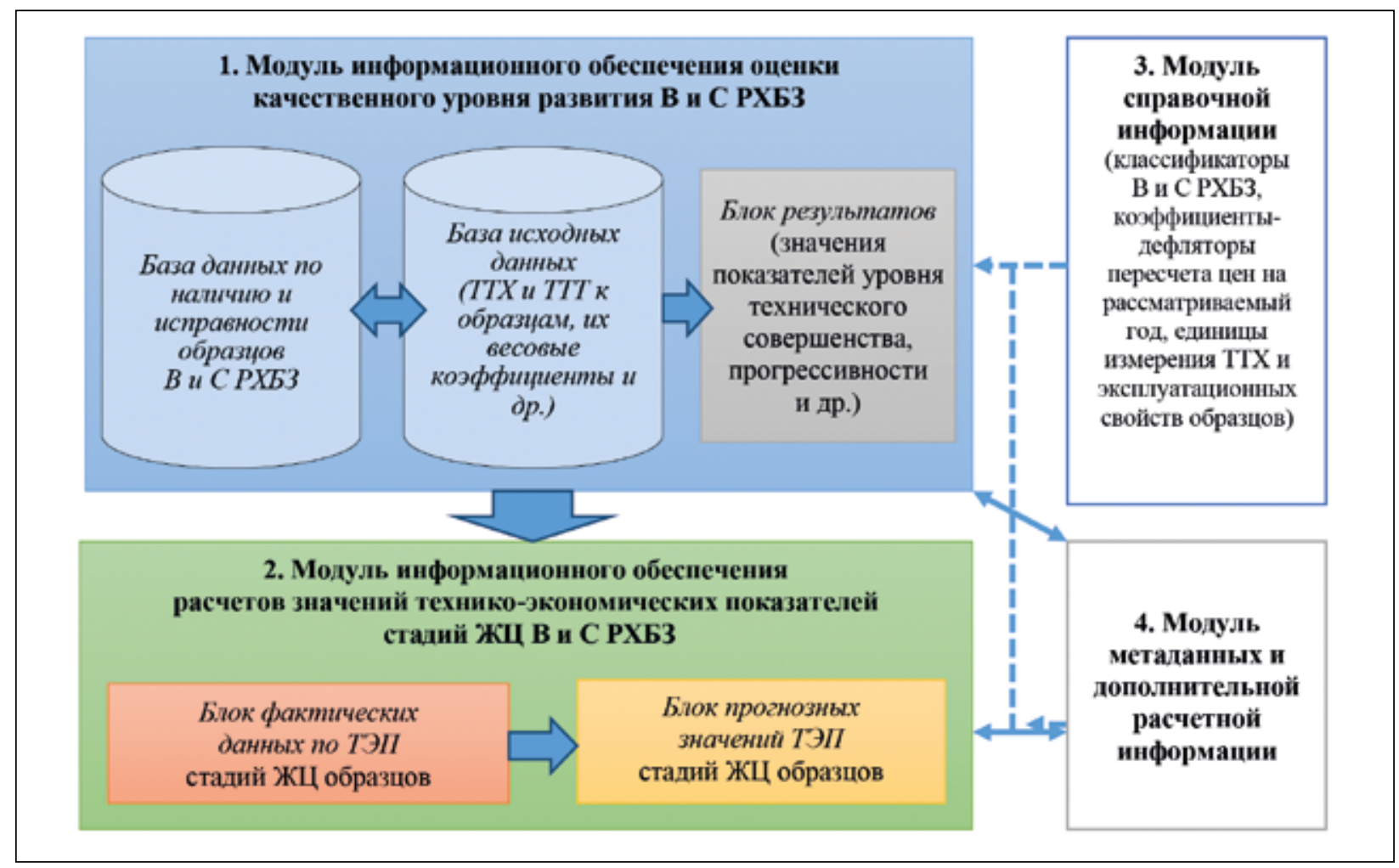

Рисунок 2 - Состав структурных элементов базы данных ИВК

показателей стадий их жизненного цикла, анализу динамики изменения состояния парка в ходе выполнения программных мероприятий развития вооружения. В совокупности взаимосвязь этих модулей образует информационную модель процессов совершенствования В и С РХБЗ в течение заданного временного периода планирования. Структура взаимосвязей базы данных ИВК приведена на рисунке 2.

Базы данных ИВК. При разработке БД ИВК предлагается применять реляционный подход, широко используемый в области проектирования сложно структурированных информационных систем с их последующей автоматизацией. Реляционная модель данных представляет собой конечный набор отношений, используемых для представления объектов и их параметров, а также для отражения связей между ними [3].

Установление совокупности отношений, содержащих логически связанную информацию, обеспечивает целостное и непротиворечивое хранение данных, необходимых для функционирования клиентского приложения «Оптимизация».

Его программная реализация направлена на аналитическую обработку промежуточных данных в режиме реального времени, получение многовариантных прогнозных оценок развития системы В и С РХБЗ, а также реализацию возможности обработки множества различных управленческих решений поставленной задачи для удовлетворения потребностей ВС РФ [4]. Информационно-аналитическое обеспечение принятия решения показано на рисунке 3.

Структура ИВК и направленность разработки БД и программ для функционирования его элементов (модулей) нацелены на создание автоматизированного информационно-аналитического обеспечения для принятия управленческих решений, концепция применения которого будет базироваться на трех уровнях (этапах) решения задач:

- информационный уровень - заключается в обеспечении поиска, сбора, хранения и распространения информации;

- аналитический уровень - реализует возможность обобщения, классификации информации, ее анализа (оперативного и интеллектуального) и дальнейшего преобразования, разработки выводов, предложений, рекомендаций и прогнозов;

- уровень визуализации - подготовка результатов анализа для эффективного их восприятия пользователем [5].

Информационный уровень использует реляционную базу данных, включающую предложения по разработке перспективных образцов В и С РХБЗ, прогнозные сроки проведения НИОКР по их созданию, лимитные цены, возможные объемы производства, закупки и 


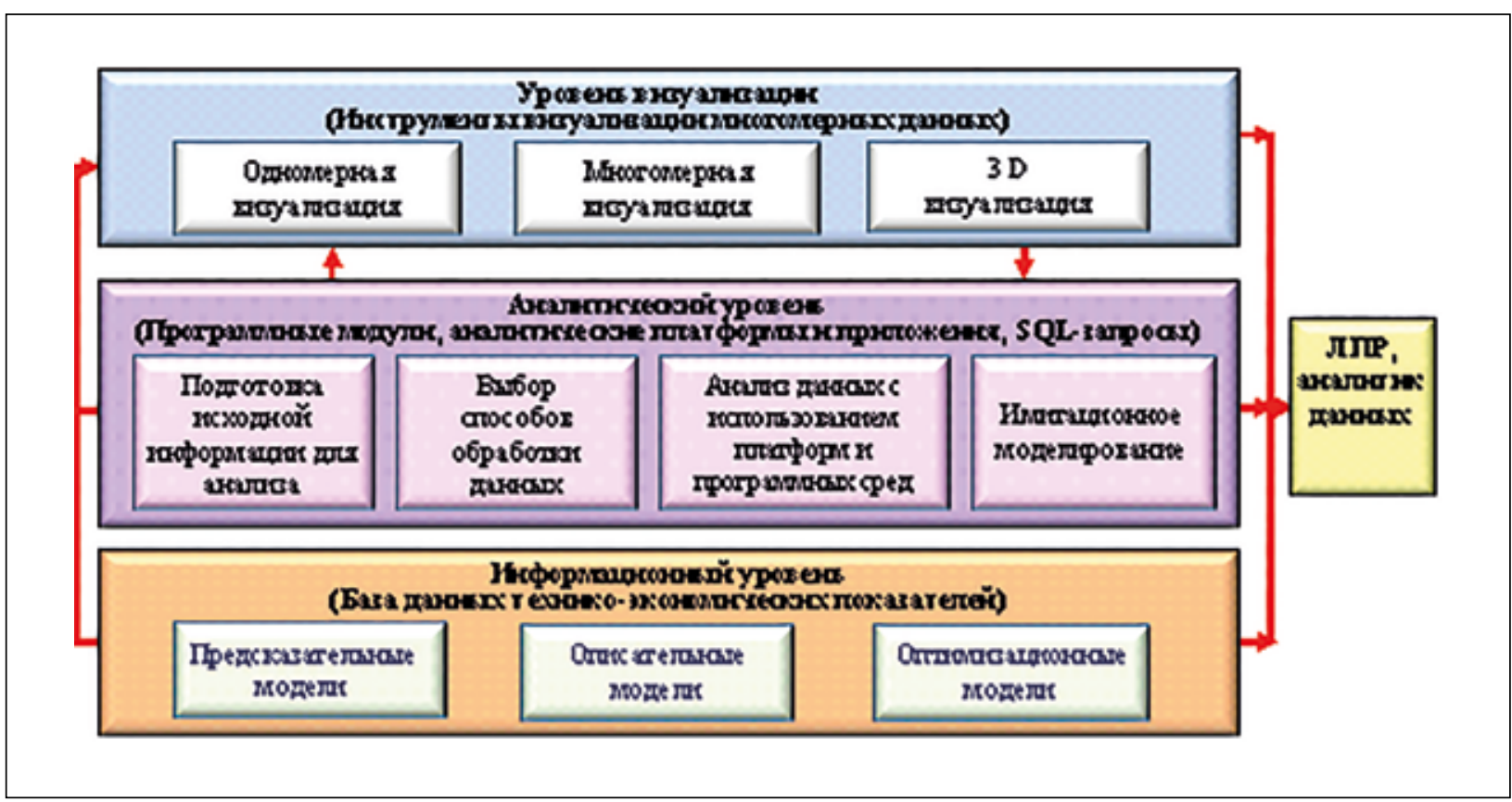

Рисунок 3 - Информационно-аналитическое обеспечение принятия решения

эксплуатации образцов, а также значения показателей технологической и экономической реализуемости. Структурно в состав этой базы могут быть включены несколько групп таблиц, предназначенных для оценки качественного развития В и С РХБЗ, содержания сведений по образцам и их зарубежным аналогам, стоимостным и временным параметрам стадий жизненного цикла образцов, а также таблицы дополнительных данных, обеспечивающий обработку промежуточных расчетов.

Аналитический уровень обеспечивает подготовку исходных данных для проведения исследований по обоснованию перспектив развития В и С РХБЗ. Для подготовки исходных данных (таблиц) достаточно использования языка запросов SQL в стандартных режимах работы - мастера запросов, обеспечивающих формирование выборки (набора) информации, применяемой в исследованиях. Дальнейшую обработку исходных данных необходимо предусмотреть в следующих трех направлениях.

Первое направление заключается в использовании программных модулей (клиентских приложений), которые реализуют существующее научно-методическое обеспечение обоснования перспектив развития В и С РХБЗ. В рамках данного направления разработаны проекты программных модулей, обеспечивающих решение расчетных задач при формировании и выборе рационального варианта развития [6-9].

Второе направление реализуется посредством применения различных аналитических инструментов и платформ, таких как Weka,
Deductor Studio, Knime Analytics Platform, библиотек анализ данных Python (Pandas, matplotlib) и инструментов аналитики MS SQL Server. Перечисленные среды разработки программ предназначены для обработки многомерных массивов информации и обеспечивают реализацию предсказательных (основанных на статистических данных), описательных и оптимизационных моделей.

Третье направление заключается в применении существующих технологий имитационного моделирования (агентное, дискретно-событийное), обеспечивающих формирование динамических моделей изменения состояния развития системы В и С РХБЗ в целом в течение заданного периода планирования.

Уровень визуализации. Несмотря на то, что все современные аналитические среды разработки имеют встроенные средства визуального двумерного и трехмерного представления информации, визуализацию данных необходимо вынести в отдельный уровень визуализации. Так как в рамках решения вопросов обоснования планов развития В и $\mathrm{C}$ РХБЗ наглядное представление результатов исследований ведет к снижению использования агрегированных и комплексных показателей (различные виды сверток, усредненные значения рассматриваемых показателей и другие), выбор конкретного алгоритма визуализации будет зависеть от объема представляемой информации и степени ее детализации.

Таким образом, разработанные концептуальные положения, лежащие в основе создания автоматизированного информацион- 
но-вычислительного комплекса обоснования проектов программ и планов развития В и С РХБ3, определяют порядок организации информационного взаимодействия ИВК с другими автоматизированными системами Министерства обороны России и оборонно-промышленного комплекса, структуру функционирования ИВК при решении расчетных задач, состав и организацию взаимодействия собственных БД, а также организацию проведения автоматизированной информационно-аналитической работы в интересах обеспечения принятия решений в области развития В и С РХБЗ. В резуль- тате проведенных исследований заложена основа создания автоматизированного комплекса видового уровня, содержащего в программном виде научно-методический аппарат разработки проекта государственной программы вооружения и обеспечивающего информационную и техническую поддержку управления развитием В и С РХБ3 на среднесрочную и краткосрочную перспективу. Внедрение ИВК в практику программно-целевого планирования позволит повысить оперативность и обоснованность принятия решений в области развития системы вооружения войск РХБ защиты.

\section{Информация о конфликте интересов}

Авторы заявляют, что исследования проводились при отсутствии любых коммерческих или финансовых отношений, которые могли бы быть истолкованы как потенциальный конфликт интересов.

\section{Сведения о рецензировании}

Статья прошла открытое рецензирование двумя рецензентами, специалистами в данной области. Рецензии находятся в редакции журнала и в РИНЦе.

\section{Список источников}

1. Хелд Г. Технологии передачи данных: 7-е издание. Спб.: Питер, 2003.

2. Вугт B.B. Open XML кратко и доступно. M.: Microsoft Press, 2007.

3. Власовец А.М. Основы проектирования реляционных баз данных: учеб. пособие для вузов. СПб.: Изд-во СПбГУЭФ, 2001.

4. Питер Р. Системы баз данных: проектирование, реализация и управление. СПб.: БХВ-Петербург, 2004.

5. Романова И.К. Современные методы визуализации многомерных данных: анализ, классификация, реализация, приложения в технических системах // Наука и образование. МГТУ им. Н.Э. Баумана. 2016. № 03. С. 133-167. https://doi. org/10.7463/0316.0834876

6. Информационно-расчетный модуль оценки затрат: свид. РФ № 2011612603 / Ерин А.Е., Скобликов Г.В., Чешев Д.Н.; заявитель и правообладатель ФГБУ
«33 ЦНИИИ» Минобороны России. № 2011610898; заявл. 14.02.11; опубл. 30.03.11.

7. Информационно-расчетный модуль определения технического уровня: свид. РФ № 2012610374 / Ерин А.Е., Скобликов Г.В., Чешев Д.Н.; заявитель и правообладатель ФГБУ «33 ЦНИИИ» Минобороны России. № 2011618496; заявл. 10.11.11; опубл. 10.01.12.

8. Программа для определения рациональных сроков обновления парка специализированной техники: свид. РФ № 2016661990 / Чешев Д.Н., Ерин А.Е., Скобликов Г.В.; заявитель и правообладатель ФГБУ «33 ЦНИИИ» Минобороны России. № 2016619281; заявл. 31.08.16; опубл. 26.10.16.

9. Программа формирования рационального варианта развития парка специализированной техники: свид. РФ № 2018613065 / Ерин А.Е., Дурнов А.С., Скобликов Г.В. и др.; заявитель и правообладатель ФГБУ «33 ЦНИИИ» Минобороны России. № 22018610242; заявл. 10.01.18; опубл. 02.03.18.

\section{Об авторах}

Федеральное государственное бюджетное учреждение «33 Центральный научно-исследовательский испытательный институт» Министерства обороны Российской Федерации, 412918, Российская Федерация, г. Вольск-18 Саратовской обл., ул. Краснознаменная, д. 1.

Чешев Дмитрий Николаевич. Научный сотрудник научно-исследовательского отдела, канд. техн. наук.

Дурнов Алексей Сергеевич. Начальник научно-исследовательского отдела, доц., канд. техн. наук.

Скобликов Григорий Владимирович. Старший научный сотрудник научно-исследовательского отдела, канд. эконом. наук.

Егорушкин Дмитрий Андреевич. Младший научный сотрудник научно-исследовательского отдела.

Контактная информация для всех авторов: 33cnii-fes@mil.ru Контактное лищо: Скобликов Григорий Владимирович; 33cnii-fes@mil.ru 


\title{
The Concept of Creating an Automated Information and Computing Complex for Substantiating Projects of Programs and Plans for the Development of Arms and Means of Radiation, Chemical and Biological Protection
}

\author{
D.N. Cheshev, A.S. Durnov, G.V. Skoblikov, D.A. Egorushkin \\ Federal State Budgetary Institution «The 33 Central Research Test \\ Institute» of the Ministry of Defense of the Russian Federation, \\ Krasnoznamennaya Street 1, Volsk-18, Saratov region 412918, Russian Federation
}

\begin{abstract}
The new stage of military construction makes it necessary to apply more advanced approaches to the functioning of the program management system for the development of weapons in order to adequately respond to emerging problems related to the formation, implementation and adjustment of plans to strengthen the country's defense in accordance with the current military-political and economic conditions of their implementation. The trend towards a continuous increase in the volume of processed information, strengthening of requirements to the efficiency of the formation of projects, programmes and plans of military construction, as well as the accuracy of the models and methodologies used to predict outcomes of activities in the field of defence and security of the country, determine the relevance of a comprehensive automation of the processes of substantiation of prospects of development of arms and means of radiation, chemical and biological protection, which can be provided by the introduction of modem information technologies, advanced methods of data analysis and improved scientific and methodological support into the practice of software management of weapons development. The purpose of the research is to create an information and computing complex to support decision-making on improving the armament system of radiation, chemical and biological protection on the basis of modern information computer technologies and methodological support for the justification of programs and development plans of arms and means of radiation, chemical and biological protection. The work is based on the methods of database design and development, system analysis, relational algebra, and object- oriented approach to the formation of automated systems. In the course of the research conceptual provisions were developed, that define the circuit operation, the structure and content of the database information and computing complex, organization of the automated information and analytical work in support of decision-making in development of arms and means of radiation; chemical and biological protection.
\end{abstract}

Keywords: database; arms and means of radiation, chemical and biological protection; information and computing complex; support of decision-making; software; programs and development plans.

For citation: Cheshev D.N., Durnov A.S., Skoblikov G.V., Egorushkin D.A. The concept of creating an automated information and computing complex for substantiating projects of programs and plans for the development of arms and means of radiation, chemical and biological protection // Journal of NBC Protection Corps. 2020. V. 4. № 2. P. 160-167. https://doi.org/10.35825/2587-5728-2020-4-2160-167

\section{Conflict of interest statement}

The authors declare that the research was conducted in the absence of any commercial or financial relationship that could be construed as a potential conflict of interest.

\section{Peer review information}

The article has been peer reviewed by two experts in the respective field. Peer reviews are available from the Editorial Board and from Russian Science Citation Index database. 


\section{References}

1. Held G. Technologies of data transfer: 7th edition. Saint Petersburg: Peter, 2003 (in Russian).

2. Vugt V.V. Open XML is short and accessible. Moscow: Microsoft Press, 2007 (in Russian).

3. Vlasovets A.M. Fundamentals of relational database design: textbook, textbook for universities. Saint Petersburg: SPbGUEF, 2001 (in Russian).

4. Peter R. Systems of database: design, implementation and management. Saint Petersburg: BHV-Petersburg, 2004 (in Russian).

5. Romanova I.K. Modern Methods of Multidimensional Data Visualization: Analysis, Classification, Implementation, and Applications in Technical Systems // Science and Education: Scientific Publication of BMSTU. 2016. № 03. P. 133-167. https:// doi.org/10.7463/0316.0834876 (in Russian).

6. Information and calculation module for cost estimation: certificate Russian Federation № 2011612603 / Erin A.E., Skoblikov G.V., Cheshev D.N.; applicant and copyright holder of FSBI «33 CRTI» Ministry of defense of Russia. № 2011610898; declared. 14.02.11; publ.

\subsubsection{1 (in Russian).}

7. Information and calculation module for determining the technical level: certificate Russian Federation № 2012610374 / Erin A.E., Skoblikov G.V., Cheshev D.N.; applicant and copyright holder of FSBI «33 CRTI» Ministry of defense of Russia. № 2011618496; declared. 10.11.11; publ. 10.01.12 (in Russian).

8. Program for determining the rational terms of updating the fleet of specialized equipment: certificate Russian Federation № 2016661990 / Cheshev D.N., Erin A.E., Skoblikov G.V.; applicant and copyright holder of FSBI «33 CRTI» Ministry of defense of Russia. № 2016619281; declared. 31.08.16; publ. 26.1016 (in Russian).

9. Program for the formation of a rational option for the development of a fleet of specialized equipment: certificate Russian Federation № 2018613065 / Erin A. E., Durnov A.S., Skoblikov G.V., et al.; applicant and copyright holder of FSBI «33 CRTI» Ministry of defense of Russia. - № 22018610242; declared. 10.01.18; publ. 02.03.18 (in Russian).

Authors

Federal State Budgetary Establishment «33 Central Scientific Research Test Institute» of the Ministry of Defence of the Russian Federation, 1 Krasnoznamennaya Street, Volsk-18, Saratov Region 412918, Russian Federation.

Dmitry Nikolayevich Cheshev. Researcher, Candidate of Technical Sciences.

Alexy Sergeevich Durnov. Chief of the Department, Candidate of Technical Sciences.

Grigory Vladimirovich Skoblikov. Senior Researcher, Candidate of Economic Sciences.

Dmitry Andreevich Egorushkin. Junior Researcher.

Contact information for all authors: 33cnii-fes@mil.ru Contact person: Grigory Vladimirovich Skoblikov; 33cnii-fes@mil.ru 